\title{
The Evolution of Beninese Political System, C. 1960-2020
}

\author{
Adohounde Yaovi Sylvestre ${ }^{1} \&$ Agonnoude Bidoley Vianney Freddy ${ }^{1}$ \\ ${ }^{1}$ Department of Political Analysis and Management \& Department of Foreign Languages, RUDN University, \\ Moscow, Russia \\ Correspondence: Adohounde Yaovi Sylvestre, RUDN University, 117198 Street Miklukho-Maklaya 13, Moscow, \\ Russia.E-mail: oksmall@mail.ru
}

Received: September 4, 2020

Accepted: October 8, $2020 \quad$ Online Published: October 13, 2020

doi:10.5539/jpl.v13n4p164

URL: https://doi.org/10.5539/jpl.v13n4p164

\begin{abstract}
The change of political system in the Republic of Benin has always been a source of conflict between its political figures, since this system represents the structure around which the country must politically be built and be developed. The article analyzes the multiple transformations of the Beninese political system since its independence in August 1960 to date. The authors highlight the strong political tensions that existed within the country, followed by multiple military coups as one of the results of these transformation processes. In this article we analyze, the four major stages that led to an evolution of the political system in Benin. This includes the independence period with the impact of French constitutional law, the revolutionary period setting up the beginning of socialist ideology with General Mathieu Kérékou, the conference of the nation's active forces of February 1990, and the undergoing reforms initiated by President Patrice Talon since 2016. The authors conclude by appreciating the reform efforts of Talon's government, which aim to modernize and strengthen the Beninese political system in the face of contemporary challenges.
\end{abstract}

Keywords: Dahomey, Dahomey Republic, Republic of Benin, independence, political system, political problems, political change, state, confrontation

\section{Introduction}

In fact, the forming process of the political system of a State is very complex and needs a very careful and thorough study. The analysis of the forming of such system depends on various factors (Telin, 2018). One of these factors in this study case of the political system in the Republic of Benin is colonization. As for the system theory, it is important to emphasize the contribution of the French anthropologist and ethnologist Claude Lévi-Strauss with the systemic approach in the field of social sciences. Hence, in his book "Structural anthropology", Claude LéviStrauss explains that, when a component pertaining to a certain system of interdependence with other components, we notice as well a change of the remaining components forming that system. Claude Lévi-Strauss even adds that the system in question may not necessarily be in harmony because of contradictions and conflicts (Claude LéviStrauss, 2001). That is the reason why it is difficult to find a political system in which there is neither confrontation, nor dysfunction.

Benin from independence to date has experienced many changes of its political system. In actual fact, the political system change remains a newsreel theme since it indicates the end of a governance sometimes inefficient or oldfashioned to the benefit of a new system of governance which fits the realities of the present, as it is noticeable today with Patrice Talon's government in Benin. Political change is highly linked to a social process since it aims at the well-being of the citizens in a safe and efficient system. Political change is an interdependent change of political institutions, standards, values and models of political behavior. It is also shown in some cases as a process of reformation of the existing system in order to get a political system much more efficient and suitable. It should be noted that the standard transformation of a political system goes through the following stages: the destruction or destabilization of the existing political system, the creation of a new political system with strong institutions and laws adapted to the system and a relative consolidation of the new political system. In this article, the evolution of the political system in Benin is first conditioned by the change of the political system in 1972 with the power seizure by Mathieu Kérékou, second by the conference of the nation's active forces in 1990 and last by the rise to power of Patrice Talon in 2016. 


\section{Methodology}

The methodology of this article is based on the use of various research approaches such as systemic approach, institutional method, anthropological approach and comparative analysis. The systemic approach was used to analyze in a gradual order on different period over the years, the evolution of the political system in the Republic of Benin. It has also ensured each time to create a link between the different political systems experienced in the country in order to have a noticeable and logical analysis of the political situation studied (the present one). The institutional method has helped to analyze reforms undertaken by President Patrice Talon especially at the level of institutions necessary for democracy in Benin, like the Constitutional Court and political parties. Thanks to the anthropological approach it has been possible to study the actions of influential figures, for example General Mathieu Kérékou who, despite his political status, was wise enough to call for the Conference of the nation's active forces. The comparative analysis has helped to link the change and the efficiency of the political system in 1990 and the new reforms of President Patrice Talon since 2016.

\section{Main Part}

The analysis of the formation of the political system in Benin as well as the different stages of its evolution is made on the basis of political events having a direct link with the history of the country. So the different stages of the evolution of Beninese political system are divided into four groups characterizing each a given period.

\subsection{First Stage: 1960 Independence}

The West African area is one of the continent regions having been ruled by country colonizers and which of course has experienced a management with severe drawbacks. The management model did not initially involve a real implication of the native populations and disqualified their decision making power. Benin, a former French colony, got its Independence in 1960 (Yacono, 1975). Before its Independence, Benin (formerly called Dahomey) voted "yes" on September 28th, 1958 referendum establishing the French community. After being proclaimed Republic of Dahomey on December 4th of the same year, Sourou Migan Apithy took the position of President of the Government Council. The name of the country was changed and officially became Republic of Dahomey. However, it is important to mention that after obtaining its independence in 1960, the Republic of Dahomey stayed under French influence till 1972. The so-called French influence started with the imitation of French constitutional right and the first President of the Republic Hubert Maga openly assuring to maintain close relations with the former colonial mother country, France. Such a statement appeared to clarify that the Republic of Dahomey was not willing to take its own destiny in hands by establishing laws adapted to its culture and its citizens' way of living. But what could be expected from a country fresh out of French domination and which is not in absolute control of its monetary policy?

In 1963, the actual installation of a political system was started with the introduction of many orders enabling a good management of the State. Among those orders, can be found some laws establishing Special Courts, some laws defining the determining the member composition of ministerial cabinets in Ministries of Public Service, Post and Telecommunication, Transport and Tourism, Foreign Affairs and Justice, etc. The Republic of Dahomey thus started to experience a new political system (its first as an independent country). In order to suppress tripartism, which divided the political league in the country and to promote monopartism, political figures came together and created The Dahomean Unity Party « Parti Dahoméen de l'Unité ». But swiftly by October 1963, a military coup was organized with the death of colonel Soglo. This coup was not the only one, as between 1960 and 1972, 12 military coups were organized with only five (5) being successful (Amoussou, 2009). It shows the high level of political instability and the poor management of the country by the newly emerged political figures. It is important to note that ethno-regionalism played an important role in the military coups tendency, since political figures of the country were supported by some strong ethnic groups. The Republic of Dahomey from 1960 to 1968 experienced the adoption of 3 constitutions. The first one in 1960 during the independence period, the second one in 1964 after a referendum and the third one in 1968, which gave Emile Derlin Zinsou the opportunity to become President of the Republic. Regarding the 1964 referendum, it is important to remember that due to social unrest in 1963 in the country, the army seized power from President Hubert Maga (democratically elected) by a coup d'etat. This decision of the army led three months later to the formation of a civilian government to which the army entrusted the provisional task of managing the country (Philippe David, 1998). For this purpose were chosen Sourou Migan Apithy as president and Justin Ahomadegbé as his prime minister. So, after the referendum of January 5th 1964, the second constitution of the country - following that of 1960 - was adopted on January 11th of that same year. Let us note that this referendum of 1964 had the merit of putting an end to the political crisis into which the country was getting. (Jean-Pierre Maury, 2006). But due to leadership rivalries between the two politicians at the head of the state, the stability brought by the new constitution was short-lived. 


\subsection{Second Stage: The Marxism-Leninism's Adoption Period}

After the military coup of October 1972 causing no casualty, General Mathieu Kérékou seized power; thus, the executive power officially went back to Beninese army. In 1974 Mathieu Kérékou, as the head of State announced the development lines of the country including the Marxism-Leninism ideology (Novikov, 1991). A revolutionary military government was established and the Benin Popular Revolution Party was created (PRPB). In that same year the Republic of Dahomey became 'The Popular Republic of Benin'. It should be noted that in 1977 a new constitution was adopted, which helped the State put forward new management strategies for key sectors for the development, such as the adoption of agrarian reforms, the implementation and development of industrialization.

In 1980 the economic situation became critical and President Mathieu Kérékou found himself in a political constraint which led him to negotiate some agreements with the International Monetary Fund (IMF). In order to realize a political achievement, and given the democratic change in some East European countries especially Russia in the 1990s the head of State moved toward liberalism and called for a national conference which aimed at establishing new basis for the development of the political system. Despite losing his position as, one should have in mind that after 18 years in power, Mathieu Kérékou is the man who had opened the door to multipartism in the Republic of Benin.

\subsection{Third Stage: The February 1990 Conference of the Nation's Active Forces}

The 1990 conference put an end to the ideology of Marxism-Leninism introduced by President Mathieu Kérékou with the adoption of a new Constitution. The main aim of that conference was to establish multipartism while decentralizing the power. During the conference, the Republic of Benin experienced an important constitutional change. Without detailing the causes and conditions in which the conference has been organizedone should henceforth remember that the President of the Republic is now eligible for 2 terms, between age 40 and age 70 .

In a completely transformed political system by the referendum which had led to the adoption of a new constitution, the Republic of Benin experienced in 1991 its first presidential election. Taken as the most democratic election of the country after its independence in 1960, Nicéphore Dieudonné Soglo was elected President on March $24^{\text {th }}, 1991$. Power was henceforth decentralized in a merely democratic regime with a working political system containing executive, legislative and judicial powers. Let us observe that the referendum of December 1990 was internationally recognized as a courageous and wonderful step toward democracy. One should observe that Benin was the first country in francophone Africa to opt for a constitutional referendum putting an end to an autocratic political system and beginning a democratic political system.

\subsection{Four Stage: Patrice Talon's Governance}

Patrice Talon's rise to power in 2016 (France Diplomatie, 2019) with the motto 'New Start' to say that there is a new way of ruling the country, different from the one of his predecessor Thomas Boni Yayi (2006-2016) under which Benin recorded the worst political and economic scandals of its history (CENSAD scandal, agricultural engines scandal, ICC service scandal to mention but a few). Patrice Talon's term gets the credit of putting Benin on the path of development by implementing new reforms and adopting bills aiming at putting forward for the long term, a new dynamic for the political system of the country. Those reforms include various life aspects of the country especially the judicial administration, the public administration, the media, security and defense, international cooperation and diplomacy. It is observable that Patrice Talon devoted a good deal of his presidential term to implementing political reforms. His first intention as far as political reforms are concerned, is the reestablishment of a State respecting the democratic process. In actual fact, it is evident that the Constitution of December $11^{\text {th }}, 1990$ gives an excessive power to the President of the Republic who has control over different institutions of the country by having in hand the State resources. To avoid any action to hinder democracy and citizens' rights and liberty, some key-measures leading to reforms in the political system in Benin, have been taken by the government of Patrice Talon. These include reforms at the level of the Constitutional Court, the Supreme Court, the High Authority of Audiovisual and Communication (HAAC), the Presidency of the Republic and finally political parties (Talon, 2015).

Reforms in Constitutional Court consist in modifying its structure by changing its way of appointing its members and the duration of their term. Such a reform will contribute to ensure the independence of that institution towards other state organizations of which it is in charge of ensuring its right running. That's to say that the members of the Constitutional Court will not be elected by the committee of the Parliament as required by the Constitution of December 1990. But they will be elected by their peers especially lawyers, lecturers of law, magistrates, former presidents of Republic and a committee composed of members of Parliament. Supreme Court's reforms have the same aim as those of the Constitutional Court. The President of Republic will not appoint the president of the Supreme Court anymore. His appointment is only reserved to his peers of the Supreme Court. As forthe High 
Authority of Audiovisual and Communication (HAAC), a change is subject to be realized. If the President of the Republic had the privilege to appoint the president of the High Authority of Audiovisual and Communication (HAAC), he will henceforth be appointed by two members chosen by a committee of the Parliament, the president of the Republic and Six former members of the media professional body. When it comes to the level of the Presidency of the Republic, there was a failed attempt to introduce a unique term of 7 years for any elected President and a cancelation of the possibility for ever running for that office in the future. Former Heads of State would not be able to run for office either, after such change; it meant that every president in Republic of Benin would henceforth hold office for only one term (unless he had performed this function temporarily by stepping in as President of the Parliament due to vacancy of the position). The reform of the political parties is the most important with no discrimination against other reforms since political parties' liberty in the Republic of Benin, according to the majority of scientific observers, epitomizes the democracy scale of the country. In so doing, Patrice Talon's government got them to pass a legislation which consists in establishing from 2016 an annual allowance of about $0.5 \%$ of State owned resources to political parties. That allowance will be divided according to the political and electoral burden without forgetting the geographical influence of each party, for henceforth in the Republic of Benin, political parties must be represented all over the territory before being allowed to participate in elections. It must be noted that such reforms must be promoted for it favors positively the political system change permitting thus to dam up the proliferation of ethnic political parties.

\section{Conclusion}

To summarize, we can state the Republic of Benin is a country which has been through strong political tensions since its independence in 1960. These political tensions were the results not only of political interference from colonial countries, but also of the lack of political experience of the Beninese elite, especially when it comes to issues of national legitimacy. Political instability suggests sometimes that the personal interest of every political personality was put before the wellbeing of a whole Nation. It is unacceptable for such a young country as Benin, which became independent after a strong domination from France, on its own territory, to be destroyed by the personal interests of its political figures, especially those from the sixties and seventies. In order to alleviate a political instability leading to a national political crisis in the Republic of Benin, the country had experienced several mutations and transformations of its political system. These mutations and transformations have been individually analyzed on one side and on the other depending on the periods in which they were. It is important to note that these transformations of the political system in the Republic of Benin were of great importance, for they enabled the country to advance politically and most importantly to gain experience when it comes to managing coups. We should point out that this evolution was made possible due to some important factors like the repeating coups and the economic crisis of the eighties, which pushed political figures towards a radical change for some (partly for those in power), but was also beneficial for others (generally for the ones in the opposition).

The different stages of the formation and evolution of the political system in the Republic of Benin are conditioned by the political history of the country. Those stages started from independence, for French colonization played an important role in the decision making process of the Dahomean elite. The influence of French democracy is especially noticeable during introductions of new constitutions with the imitation of French Constitutional laws which is embedded in all those of the country. The socialistic orientation of Mathieu Kérékou's government, despite having the reputation of ruling harshly by establishing monopartism, could not have come out of the economic crisis of the 80s, which drowned the Republic of Benin in a dreadful chaos and in a politico-economic crisis never experienced. The conference of the Nation's active forces in February 1990 followed by the referendum of December 11th, 1990 totally changed the political system in the Republic of Benin. One will remember that a democratic regime (the first in francophone Africa) arose with the emergence of multipartism and terms limitation of heads of State. After 30 years of peaceful constitutional life, a tribute is due to Patrice Talon's government for bringing changes to the Beninese political system. But it is important to note that the results deriving from that new political change undertaken by Patrice Talon's government can only be appreciated in the future for it is early to talk about the benefits of that new political change in Benin.

\section{References}

Bruno, A. (2009). L'Afrique est mon combat. L'Archipel,96-104.

Claude Lévi-Strauss. (2001). L'anthropologie structurale. Exmo press.

France Diplomatie. (2009). Présentation $d u \quad B e ́ n i n . \quad$ Retrieved August 29, 2020, from https://www.diplomatie.gouv.fr/fr/dossiers-pays/benin/presentation-du-benin/

Histoire du Bénin. In Wikipedia, the free encyclopedia. Retrieved July 9, 2020, from https://fr.wikipedia.org/wiki/Histoire_du_Bénin\#cite_ref-4 
Maury, J.-P. (2006). République du Bénin (ex Dahomey). Retrieved October 2, 2020, from https://mjp.univperp.fr/constit/bj.htm

Novikov, O. A. (n.d.). The political system of the Republic of Benin: formation and development trends. Moscow State Institute of International Relations of the Ministry of Foreign Affairs of the USSR, 21.

Perspective monde. (2019). Bénin. Retrieved July 9, 2020, from https://perspective.usherbrooke.ca/bilan/servlet/BMPays?codePays=BEN

Philippe, D. (1998). Le Bénin. Karthala. 56-59.

Site officiel de la Présidence de la République du Benin. (2020). Histoire du Benin. Retrieved October 2, 2020, from https://presidence.bj/home/le-benin/histoire/

Talon, P. (2015). Réformes politiques. Retrieved July 10, 2020, from https://patricetalon.com/portfolio-posts/lom/

Telin, K. O. (2018). Stability of political systems: dynamics and identifiers. Moscow University Press.

Xavier, Y. (1975). Les Étapes de la décolonisation française, Presses universitaires de France (réédition numérique FeniXX).

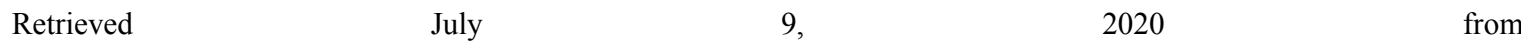
https://books.google.ru/books?id=YzeOAAAAMAAJ\&q=inauthor:\%22Xavier+Yacono\%22\&dq=inauthor:\%22Xavier+ Yacono\%22\&hl=fr\&sa=X\&ved=2ahUKEwj916PEjsDqAhVqw4sKHfAlD-IQ6AEwBXoECAYQAg

\section{Copyrights}

Copyright for this article is retained by the author(s), with first publication rights granted to the journal.

This is an open-access article distributed under the terms and conditions of the Creative Commons Attribution license (http://creativecommons.org/licenses/by/4.0/). 